\title{
IMPACT OF INTERNET AIDED SELF-MANAGED TEAMS ON QUALITY OF WORK-LIFE AND PERFORMANCE
}

\author{
Dean Elmuti \\ Eastern Illinois University \\ Charleston, IL
}

\begin{abstract}
The impact of participation in an Internet aided self-managed (IASM) teams program on employee quality of work life attitudes, and on performance was studied among employees in a manufacturing firm for a 36-month period. The attitudinal results indicate that IASM teams improved participants' quality of work life. The performance results document a positive and substantial impact on employee productivity, efficiency, quality, and overall performance. However, implementation of IASM teams is a complex task that requires time and commitment of resources to reap potential rewards. In addition, the research findings suggest that using this program gives employees the authority to act and make decisions on their own, making their jobs more demanding and challenging at the same time.
\end{abstract}

\section{Introduction}

The development of the Internet and the information technology industries has forever changed the way that companies do business and create value. In light of the recent growth in "electronic commerce" (i.e., Internet or Web-based systems and the information technology (IT) industries), many private forecasts made just a year ago have been revised upward. In early 1998, forecasters were suggesting that business-to-business (B2B) e-commerce might rise to $\$ 300$ billion by 2002 (Holtz, 1996; Kezsbom, 2000). Most forecasters now consider that estimate to be too low. For example, Forrester Research (Forrester, 1998) estimates that business-to-business e-commerce will rise to $\$ 1.3$ trillion by 2003 . Cyber Dialogue (Thompson-Jones, 1999) estimates that the value of off-line orders influenced by the Internet was approximately $\$ 51$ billion. There were estimated 400 million people worldwide using the Internet in 2001. Projections called for 600 to 700 million internet users globally by 2003 (Thompson and Strickland, 2003). In addition, many organizations are using self-managed terms programs in conjunction with the internet as a tool to communicate effectively and to improve performance (Kezsbom, 2000; Alwang, 1998; Mays, 1999). Almost ten years ago, the idea of a team working together from remote locations was nonexistent. Today, technology, globalization, and the need for fast responses to marketplace demands have dramatically changed the way business is conducted. Approximately 137 million workers worldwide will be involved in some form of remote electronic work by 2003 (Solomon, 2001). 
In allowing employees to participate in problem-solving-giving them the authority to act and make decisions on their own-they develop a renewed interest in their organization's performance and therefore in improving their own performance. Management delegates authority to self-managing teams who execute the work faster and with fewer delays than were possible in the traditional organizational structure. Using the Internet as a tool to communicate effectively with each other and with teams in different locations (Kezsbom,2000; Townsend, DeMarie and Hendrickson, 1996; Alexander,2001), allows the decentralization of decision making and authority while simultaneously support centralized control (Harvey, 1999; Turban, Rainer and Porter, 2000). It is not an end in itself, but the means of achieving greater performance and improved employee quality of work life perceptions.

With the increasing us of IASM teams in work organizations and the convergence of many high-technology fields, broad longitudinal teams in work organization and the convergency of many high-technology fields, broad longitudinal investigation is needed to provide insights into the understanding of its impact on the business environment. Therefore, this article discusses a longitudinal and experimental field study that compares changes in perceptions of quality of work life and performance for participants in an Internet aided selfmanaged teams program.

\section{Literature Review}

Internet technology provides automation, allows business to be conducted in different locations provides flexibility in manufacturing, and permits quicker delivery to customers. Reducing cycle time is extremely important for increasing productivity and competitiveness (Turban, Rainer and Porter, 2000; King, 1998; Cayne, 1997). At the same time, the use of this technology has potentially adverse effects on employees such as alienation, anxiety, stress, and frustration (King, 1998; Bill, 2000). While there is little consensus about what changes occur, there is general agreement that an understanding of the consequences that information technologies (IT) have on employees' jobs is a significant and unresolved topic of investigation and research. Early studies on the impact of IT on employees were characterized by speculation of one sort or another. Several studies noted that the use of IT changed the nature of the employees' job (Bradley, 1977; Massey, 1986; Kling, 1996). A frequent criticism of traditional data processing systems has been their negative effect on people's individuality. Such systems have long been criticized as being impersonal; they dehumanized and depersonalized the activities that were computerized (Kling, 1996; Ramsey, 2000).

However, several studies (Rossman, 1986; Stokes and Stewart, 1991; Zawacki and Lackow, 1998) offered several suggestions to avoid "the pitfalls" of computerization, and one of the suggestions was to gain employee support by soliciting input from them by forming self-managed work teams. Self-managed work teams are groups of employees (5 - 12) with all the technical skills and the 
authority needed to direct and manage themselves (Dumaine, 1997; Forrester and Drexler, 1999). That is, they are appointed to manage themselves because the team members are those employees most familiar with a particular aspect of the company (Kirkman and Rosen, 2000; Herrenkohl, Judson and Heffner, 1999). Self-managed teams have been credited with saving hundreds of millions of dollars, achieving conceptual breakthroughs, and introducing an unparalleled number of new products (Anthony, Kacmar and Whitfield, 1995; Brucker, 1995; Brunelli, 1999). Self-managed team activities are also expected to lead to improved working conditions by offering greater opportunities for expression and self-development for participating employees (specifically, aspects of the "psychological quality of work life") (Holpp, 1994) as well as increased productivity and market share, improved pricing, and cost reduction (Reid and Reid, 1999).

The self-managed work team - a product of the quality circle movement in global manufacturing companies - is beginning to be used by Information Systems (IS) departments and smaller firms across a variety of settings that are willing to gamble on internal reorganization for the sake of increased flexibility, increased creativity motivation and quality, reduced employment, and reduction in overhead costs (Stokes and Stewart, 1991); McDonough and Cedrone, 2000).

Virtual teams are also becoming more and more popular in the business world today (Kezsbom, 2000; DeMarie and Townsend, 1998). Virtual teams, whose members are in different locations, frequently belong to different functional areas or different organizations, and communicate electronically. Internet technology plays a critical role in empowering team members and providing the necessary communication links among teams (Turban, Rainer and Porter, 2000). A virtual team's members are united by the tasks on which they are collaborating, not by geography or membership in a larger organization (Kezsbom, 2000). The technology is clearly available to make virtual teams possible, and the number of firms beginning to explore the potential of virtual teaming is increasing. Already companies such as Hewlett-Packard, Price-Waterhouse, Lotus Development, and Whirlpool have implemented some type of Internet aided virtual teams (Alexander, 2001; Townsend, DeMarie and Hendrickson, 1996).

One of the most highly publicized example of a company that transformed itself to a self-managed team structure aided by Internet technology is GE (General Electric Corporation) of Canada. From the beginning the steering committee that planned the transformation recognized the role of Internet technology and teams as critical factors in the transformation-both for communication and collaboration among teams, and as tools to support the whole organization. The results of the GE effort were dramatic indeed. The number of employees was reduced by $50 \%$, while the productivity of the company and the quality of its operations were drastically improved (Turban, McLean and Wetherbe, 1999).

Despite the frequency with IASM teams programs have been adopted in work organizations (Cayne, 1997; Forrester and Drexler, 1999) there is a paucity of knowledge generated by independent evaluators using rigorous 
methods as to the impact on employee attitudes and behaviors. The available studies are limited to testimonials from managers and consultants who have implemented IASM teams programs (Alwang, 1998; Fister, 1999; Reid and Reid, 1999; Mays, 1999). The central theme that runs through most of these studies reflects a common belief that the use of self-managed teams programs generally improves organizational effectiveness (McDonough and Cedrone, 2000; Townsend, DeMarie, and Hendrickson, 1996). A study conducted at the IBM plant in Lexington, KY showed that IASM team participation led to improvement in employee productivity, efficiency, quality, and a steady stream of innovations (Flanagan, 1994). A recent report on Cisco Systems indicated that Cisco has special teams that work with other companies to provide better customer service, to develop new technologies, and to help other companies implement Cisco programs. Currently, a Cisco team on Network Technology is partnering with Intel to deliver enhanced capabilities for virtual local area networks (VLAN's) to help companies reduce the costs and eliminate many of the problems that come along with managing large client/server computer networks (Alwang, 1998; Mays, 1999).

\section{Research Methodology}

\section{Research Site and Participants}

This research was conducted in one of the subsidiaries of a large, diversified, non-unionized, multidivisional pharmaceutical corporation located in an urban area in the North Eastern United States. The company had a work force of 920 employees at the time of the study. Production operations were primarily assembly using a batch process. The company is presently engaged in production, processing, distributing, and marketing its products and services worldwide. Revenues for 1998 derived from the company's three core businesses (vitamins and fine chemicals, flavors and fragrances, and diagnostics). The company was not doing well financially primarily due to intense competition from low wage countries in Asia, low productivity, limited access to new markets, high costs of advertising, and limited customer service and support. To address these problems the company management decided to utilize the IASM teams program. This was done on an experimental basis before its implementation in the entire company. A consulting group was invited to train managers and employees at all levels of the organization and to assist in the implementation of the program. The consulting group made it clear from the beginning that success depended to a large degree on the cooperation and participation of all job holders and support from senior and middle management.

As indicated earlier, the plant had a work-force of 920 employees at the time the study was planned. Four hundred and sixty employees from different functions in the plant such as production, clerical, accounting, sales, distribution functions, and newly hired Internet networks personnel were selected to participate in 45 self-managed teams at the start of the program. The number increased over a 3 - 
year period to include all full time employees in the plant. The self-managed teams that were established ranged in size from eight to twelve members.

Top management agreed to commit resources to improve operations, develop and train employees, build team work aided by Internet technology, and open communication channels. All levels of employees, including senior managers, middle managers, first line supervisors, sales staff, production workers, and machine operators were trained by the consulting group for a few weeks prior to the implementation of the Internet aided by self-managed teams program.

In order to have an accurate assessment of the consequences of the program, it was necessary to have a control or a comparison group. This control group was to consist of 460 of the 920 employees in the plant who were not selected or chose not to participate.

\section{Software/System and Training}

The primary responsibility of the consulting group was to select a suitable Internet technology that allows empowered employees - self-managed teams to access data, information, and knowledge they need for making good decisions quickly by using the Internet or intranets (corporate networks that use Internet technologies). In addition, Internet technology allows team members to communicate effectively with other teams in different locations, to purchase and market goods and services over the Internet, to maintain customer service channels, to recruit future employees, and to coordinate finances. Goals were set, the Web site was built and placed on a Web server, and efforts were made to promote the site and maintain it by the self-managed teams. In conjunction with the Internet, Electronic Data Interchange (EDI) played an important role in teams performance and supply chain management activities. EDI make information flow automatically in the supply chain and eliminates some labor-intensive processes, like data entry and re-entry between customers and suppliers (Shore, 2001). EDI has not a single universal standard. For small firms, it is very expensive to establish their EDI system. Now, because of the development of the Internet, EDI has been integrated with the Internet, and the cost of establishing an EDI system has been significantly decreased while the EDI capabilities have been increased.

In addition, the teams communicated through custom-designed and accesscontrolled Lotus Notes discussion forums. Lotus Notes is the world's leading groupware solution package and a widely used system and application development platform (Weiss, Massey and Song, 2001). Lotus Notes combines messaging, groupware, and the Internet. Through the use of Lotus Notes, corporations can implement virtual or actual teams that use e-mail, digital white boards, and data sharing. In addition, Lotus Notes enables dispersed asynchronous work by classifying entries into main topics and responses. Every message has a time stamp reveals the identify of the author. All participants accessed the forums via a Web browser and were able automatically to open and close the Lotus Notes databases, according to a predefined schedule. 
The ISAM teams training program included training in communication for effective meetings and planning, skills for cross-functional teams, and training for quality improvement including methods of identifying problems, setting priorities, discovering causes, and implementing solutions. A first line supervisor or a systems analyst usually served as team leader. Each team had its own leader to coordinate its internal workings and to represent the team with outside entities.

\section{Measures}

The following two major hypotheses have been developed to test the data from this study:
Hypothesis 1: Participants in Internet aided self-managed teams will show higher levels of improvement in quality of work life aspects than non-participants.
Hypothesis 2: Participants in Internet aided self-managed teams will report higher overall performance than non- participants.

The hypotheses are all stated to reflect the claims made by Internet aided selfmanaged teams proponents, and the findings from the literature on organizational behavior and Internet applications.

\section{Measures of Quality of Work Life Perceptions}

A questionnaire, archival data, and follow-up interviews were used to accomplish this study. The questionnaire was designed to tap a wide range of quality of work life facets, with measures derived from the Michigan Organizational Assessment Package. The Michigan instrument has been shown to have acceptable levels of reliability and validity across a variety of settings (Marks, Mirvis, Hackett and Grady, 1986; Lawler, 1979; Mirvis and Lawler, 1984). Responses were reported on seven-point scales, ranging from one (low) to seven (high) for all measures. Included in the questionnaire were measures of each of the researched quality of work life areas. Measures of participation and communication available from the questionnaire were: a self-report of the frequency with which suggestions were offered at work; an item assessing satisfaction with opportunities to take part in decisions; and, scales of work team communication.

The population sampled included all full-time employees: production workers, machine operators, supervisors, clerical, accounting personnel, sales reps, distributors, managers, and senior managers from different functional areas. A total of 920 employees were sent questionnaires via company mail. One survey was conducted at the research site just prior to the implementation of the selfmanaged team approach in conjunction with the Internet based systems program 
in order to assess employee attitudes and perceived quality of work life in the firm. Seven hundred thirty employees returned questionnaires, generating a $76 \%$ rate. A second survey was conducted 30 months after the program had begun in order to assess any changes on employee perceptions. Six hundred four employees returned the questionnaires, generating a $67 \%$ rate. Twenty questionnaires were not acceptable, however, and the response rate was lowered to $64 \%$. A demographic description of the survey respondents was compared to that of the whole population of the organization. In this way, it could be determined if the actual sample was representative of the population. The results of that comparison indicated that the demographic characteristics of both the sample and the whole population was similar in all respects.

\section{Measures of Organizational Performance - Actual Data}

Actual organizational data from the surveyed firm (productivity, quality and other performance indicators) was used to assess the impact of (IASM) teams on employee performance.

Productivity was measured by the ratio of output produced to resources used. Three productivity measures were available from organizational records: percentage of hours spent on production - actual number of hours spent on production divided by total number of available hours, efficiency rate - number of products produced within quality specifications divided by industrial engineering output rate, and overall productivity-number of actual pieces of product produced divided by number of pieces of product expected to be produced divided by total hours paid (Marks, Mirvis, Hackett and Grady, 1986; Daft, 1999). Additionally, records of quality were collected from an internal quality audit and the number of defects per finished product per 1,000 units were added and averaged per six months (Crosby, 1979).

Other performance measures included net income return on investment, growth - market share rates, and export growth (Daft and Marcic 1998; Daft, 1999). Data for each performance measure were collected for a 36 month period, ranging from six months prior to the adoption of the IASM teams program to 30 months after the program began. This length of measurement provided adequate time to assess the impact of the program on employee performance and the quality of their products. Average rates were then computed for six month intervals and compared before and after the program began. Period 1 represents the average rate for the six months prior to the program implementation; Period 2 is the average rate for the first six months the program was operational; Period 3 is the average rate for months $7-12$; Period 4 is the average rate for months $13-18$; Period 5 is the average rate for months $19-24$; and, Period 6 is the average rate for months 25 30.

Follow-up interviews were then conducted with the plant manager, human resource manager, operations manager, information systems manager, and controller in this manufacturing facility. The purpose of the interviews was to obtain a deeper perspective of the effects of the (IASM) teams program on 
employee performance as well as to assess the effectiveness of the program relative to its costs. Furthermore, the interviews were used to rule out alternative explanations for changes in employee performance in the plant. During these interviews, the participants responded to the seven-item questionnaire.

\section{Results}

\section{Analysis of Quality of Work Life Perceptions}

Table 1 presents the mean scores of the quality of work life measures for participants and nonparticipants before and after implementation of the Internet aided self-managed teams program. The results of the $t$-test indicate that participants reported significant increases in all work life areas. The Pearson Product-moment Correlation ${ }^{(1)}$ was also calculated for program and quality of work life dimensions to measure the strength, direction, and statistical significance of relationships for Internet aided self-managed teams program and the quality of work life dimensions.

Univariate F-tests were also employed across time periods for each variable to evaluate the hypotheses. As Table 2 shows, there were significant differences over time for each of the variables in the participant group before and after program implementation. The table also illustrates significant differences from program initiation between the two groups with respect to quality of work life and performance.

The influence of participation in the IASM teams program on quality of work life perceptions and performance was examined through use of multiple regression analysis. This analysis determines the proportion of variance in quality of work life perceptions and performance scores explained by IASM teams program scores. Two major variables were identified as being significant for the purpose of this study: (1) the elements used to measure the independent variables are the mean scores of all IASM teams program dimensions such as activities of identifying relevant problems and attending to their solution in a systemic and ongoing way through IASM teams program. IASM teams program allow team members to communication with each other effectively, as well as, to communicate with other teams in different locations through the Internet (Forrester and Drexler, 1999; Weiss, Massey and Song, 2001). The second variable used to measure the dependent variables are the mean scores of quality of work life perceptions and performance dimensions.

$$
\begin{aligned}
& \mathrm{H}_{1}=\mathbf{r}_{(\mathrm{IASMQP})}>0 \text { (substantive hypothesis) } \\
& \mathbf{H}_{0}=\mathbf{r}_{\text {(IASMQP })}=0 \text { (null hypothesis). }
\end{aligned}
$$

Table 3 presents the results of this analysis, which indicates positive relationship between measures of quality of work life and performance and IASM teams as reflected in the multiple regression ratios. Results show that $46 \%$ of the variation in quality of work life and $52 \%$ of the variation in performance are 
Table 1

Mean Difference Between Period 1 and Period 6 Quality of Work Life Scores for Participants and Nonparticipants in Internet Aided Self-managed Teams Program

\begin{tabular}{|c|c|c|c|c|c|}
\hline \multirow[b]{2}{*}{ Quality-of-work-life Measure } & \multicolumn{2}{|c|}{ Period 1} & \multicolumn{2}{|c|}{ Period 6} & \multirow{2}{*}{$\begin{array}{c}\text { t Value } \\
\text { (or } \\
\text { t Statistic) }\end{array}$} \\
\hline & $\begin{array}{l}\text { Mean } \\
\text { Score }\end{array}$ & $\begin{array}{l}\text { Std. } \\
\text { Dev. }\end{array}$ & $\begin{array}{l}\text { Mean } \\
\text { Score } \\
\end{array}$ & $\begin{array}{l}\text { Std. } \\
\text { Dev. }\end{array}$ & \\
\hline \multicolumn{6}{|l|}{ Suggestions offered } \\
\hline - Participants & 4.40 & 1.14 & 6.30 & .96 & $3.78 * *$ \\
\hline - Nonparticipants & 4.38 & 1.18 & 4.98 & 1.11 & $2.45^{*}$ \\
\hline \multicolumn{6}{|l|}{ Participation in decision making } \\
\hline - Participants & 2.71 & 1.24 & 5.26 & 1.66 & $2.98 * *$ \\
\hline - Nonparticipants & 2.73 & 1.38 & 2.98 & 1.38 & $-1.55^{* *}$ \\
\hline \multicolumn{6}{|l|}{ Work group communication } \\
\hline - Participants & 3.90 & 1.24 & 6.20 & 1.33 & $3.89 * *$ \\
\hline - Nonparticipants & 3.90 & 1.33 & 3.94 & 1.17 & $-1.27^{*}$ \\
\hline \multicolumn{6}{|l|}{ Organization communication } \\
\hline - Participants & 3.38 & 1.49 & 5.44 & 1.89 & $3.40^{* *}$ \\
\hline - Nonparticipants & 3.72 & 1.77 & 3.10 & 1.72 & $-1.31^{*}$ \\
\hline \multicolumn{6}{|l|}{ Meaning } \\
\hline - Participants & 4.40 & .88 & 6.10 & 1.88 & $3.08^{* *}$ \\
\hline - Nonparticipants & 4.70 & 1.32 & 4.30 & 1.62 & $-1.64^{*}$ \\
\hline \multicolumn{6}{|l|}{ Challenge } \\
\hline - Participants & 4.44 & 1.72 & 5.88 & 1.66 & $3.33 * *$ \\
\hline - Nonparticipants & 4.39 & 1.74 & 4.20 & 1.42 & $-1.78 *$ \\
\hline \multicolumn{6}{|l|}{ Personal responsibility } \\
\hline - Participants & 4.47 & .66 & 6.22 & .58 & $2.44 * *$ \\
\hline - Nonparticipants & 4.45 & .71 & 4.49 & .72 & $1.57^{*}$ \\
\hline \multicolumn{6}{|l|}{ Accomplishment } \\
\hline - Participants & 4.50 & 1.44 & 5.95 & 1.09 & $3.18 * *$ \\
\hline - Nonparticipants & 4.42 & 1.38 & 3.98 & 1.26 & $-2.09 *$ \\
\hline \multicolumn{6}{|l|}{ Advancement } \\
\hline - Participants & 4.76 & 1.80 & 5.10 & 1.66 & $1.28 * *$ \\
\hline - Nonparticipants & 4.88 & 1.66 & 3.62 & 1.42 & $-2.28 *$ \\
\hline
\end{tabular}

* All $\mathrm{p}<.05$

** $\quad$ All $\mathrm{p}<.01$

"Period 1 is prior to the implementation of the Internet aided self-managed teams program and Period 6 is after the program's inception.

explained by linear regression on the IASM teams program dimensions. The Fratios indicate that linear associations are statistically at the 0.05 level. It is, therefore, appropriate to reject the null hypotheses, and to state, with more than $95 \%$ confidence, that a positive relationship was found between quality of work life and performance measures and Internet aided self-managed teams program. 
Table 2

Results of Univariate F-tests for Differences Between Participants and Non-participants in Internet Aided Self-managed Teams Program

\begin{tabular}{|c|c|c|c|}
\hline $\begin{array}{l}\text { Dependent Variables } \\
\text { Composite Measures of } \\
\text { Quality-of-work-life } \\
\text { and Performances Perceptions }\end{array}$ & $\begin{array}{l}\text { Before the } \\
\text { Adoption of } \\
\text { the Program* } \\
(\mathbf{n}=\mathbf{9 2 0})\end{array}$ & $\begin{array}{l}\text { Thirty Months } \\
\text { after the } \\
\text { Program began } \\
(n=900)\end{array}$ & F-Value* \\
\hline \multicolumn{4}{|l|}{$\begin{array}{l}\text { Communication } \\
\text { (organization/teams) }\end{array}$} \\
\hline $\begin{array}{l}\text { - Participants } \\
\text { - Nonparticipants }\end{array}$ & $\begin{array}{l}3.38 \\
3.40\end{array}$ & $\begin{array}{l}5.95 \\
3.59\end{array}$ & $\begin{array}{l}4.26^{* *} \\
1.37^{*}\end{array}$ \\
\hline \multicolumn{4}{|l|}{$\begin{array}{l}\text { Participation } \\
\text { (suggestions/participation } \\
\text { in decision making) }\end{array}$} \\
\hline $\begin{array}{l}\text { - Participants } \\
\text { - Nonparticipants }\end{array}$ & $\begin{array}{l}3.20 \\
3.22\end{array}$ & $\begin{array}{l}5.99 \\
3.47\end{array}$ & $\begin{array}{l}2.38^{* *} \\
1.24^{*}\end{array}$ \\
\hline \multicolumn{4}{|l|}{ Job Characteristics } \\
\hline $\begin{array}{l}\text { - Participants } \\
\text { - Nonparticipants }\end{array}$ & $\begin{array}{l}3.10 \\
3.05\end{array}$ & $\begin{array}{l}6.10 \\
3.28\end{array}$ & $\begin{array}{l}5.47 * * \\
1.17 *\end{array}$ \\
\hline \multicolumn{4}{|l|}{ Growth Needs } \\
\hline $\begin{array}{l}\text { - Participants } \\
\text { - Nonparticipants }\end{array}$ & $\begin{array}{l}3.28 \\
3.22\end{array}$ & $\begin{array}{l}5.78 \\
3.38\end{array}$ & $\begin{array}{l}2.72^{* *} \\
1.04^{*}\end{array}$ \\
\hline \multicolumn{4}{|l|}{ Performance Indicators } \\
\hline $\begin{array}{l}\text { - Participants } \\
\text { - Nonparticipants }\end{array}$ & $\begin{array}{l}3.52 \\
3.47\end{array}$ & $\begin{array}{l}6.05 \\
3.58\end{array}$ & $\begin{array}{l}4.98 * * \\
1.19 *\end{array}$ \\
\hline
\end{tabular}

${ }^{*} \mathrm{p}<.05$

$* * \mathrm{p}<.01$

$\mathrm{n}=$ Number of employee dropped from 920 to 900 employees in the plant

Table 3

Multiple Regression Analysis of the Relation Between Participation in Internet Aided Self-managed Teams Perceptions of Quality of Work Life and Performance

\begin{tabular}{lccc}
\hline $\begin{array}{l}\text { Dependent } \\
\text { Variables }\end{array}$ & $\begin{array}{c}\text { Multiple } \\
\text { Regression }\end{array}$ & $\begin{array}{c}\text { Regression } \\
\text { Square }\left(\mathbf{R}_{2}\right)\end{array}$ & F-Ratio* $^{*}$ \\
\hline Quality of work life & 0.60 & 0.46 & 4.75 \\
Performance & 0.71 & 0.52 & 6.40 \\
\hline
\end{tabular}

$* p<0.05$ 
An attempt was made, through an interview with participants in the project, to assess the impact of participation in Internet on performance and quality of worklife without considering the influence of participation in a self managed teams program. Self-reports were used for this measure. Respondents were asked: (1) to what extent the quality-of-work-life and performance gains were due to the Internet; (2) whether traditionally implemented self-managed team program would achieve the same results; and (3) whether it was possible that Internet technologies could achieve the same results without self-managed teams. Table 4 presents the results that indicate a positive relationship between measures of Internet based and quality of work-life and performance as reflected in the multiple regression ratios. However, the results show only $22 \%$ of the variation in quality-of-work-life, and only $28 \%$ of the variation in performance was explained by linear regression on the Internet based technologies dimensions. The F-ratios indicate that the linear associations are statistically significant at $p<0.05$. The findings also indicate that it was not possible that Internet based technologies could achieve the same results without the aid of self-managed teams, as reflected in a significant decrease in resulting $\mathrm{R}$-squares for the quality-of-work-life and performance measures.

\section{Table 4}

Multiple Regression Analysis of the Relation Between Participation in Internet Based Technologies and Perception of Quality-of-Work-Life and Performance

\begin{tabular}{lccc}
\hline $\begin{array}{l}\text { Dependent } \\
\text { Variables }\end{array}$ & $\begin{array}{c}\text { Multiple } \\
\text { Regression }\end{array}$ & $\begin{array}{c}\text { Regression } \\
\text { Square }\left(\mathbf{R}_{2}\right)\end{array}$ & F-Ratio* $^{*}$ \\
\hline Quality-of-work-life & 0.46 & 0.22 & 4.72 \\
Performance & 0.54 & 0.28 & 3.35 \\
\hline
\end{tabular}

$* p<0.05$

\section{Analysis of Organizational Performance Impacts}

Table 5 presents average six month rates for the performance measures beginning 6 months prior to the adoption of the Internet aided self-managed team program until 30 months after the program began. For each measure the average percentage of hours spent on production went from $44 \%$ to $76 \%$ - an increase of $73 \%$; efficiency rate went from $56 \%$ to $78 \%$ - an increase of $39 \%$; overall productivity average rate went from $64 \%$ to $81 \%$ - an increase of $26.5 \%$; the average number of defects per 1,000 units went from 222 to 110 - a decrease of more than $50 \%$; net income average rate went from $4 \%$ to $10 \%$ - an increase of $1.5 \%$; return on investment average rate went from $2 \%$ to $3.6 \%$ - an increase of $0.8 \%$; market share average rate went from $2 \%$ to $3 \%$ - an increase of $0.5 \%$; and, export growth average rate went from $0 \%$ to $8 \%$. 
Table 5

Data from Organizational Records

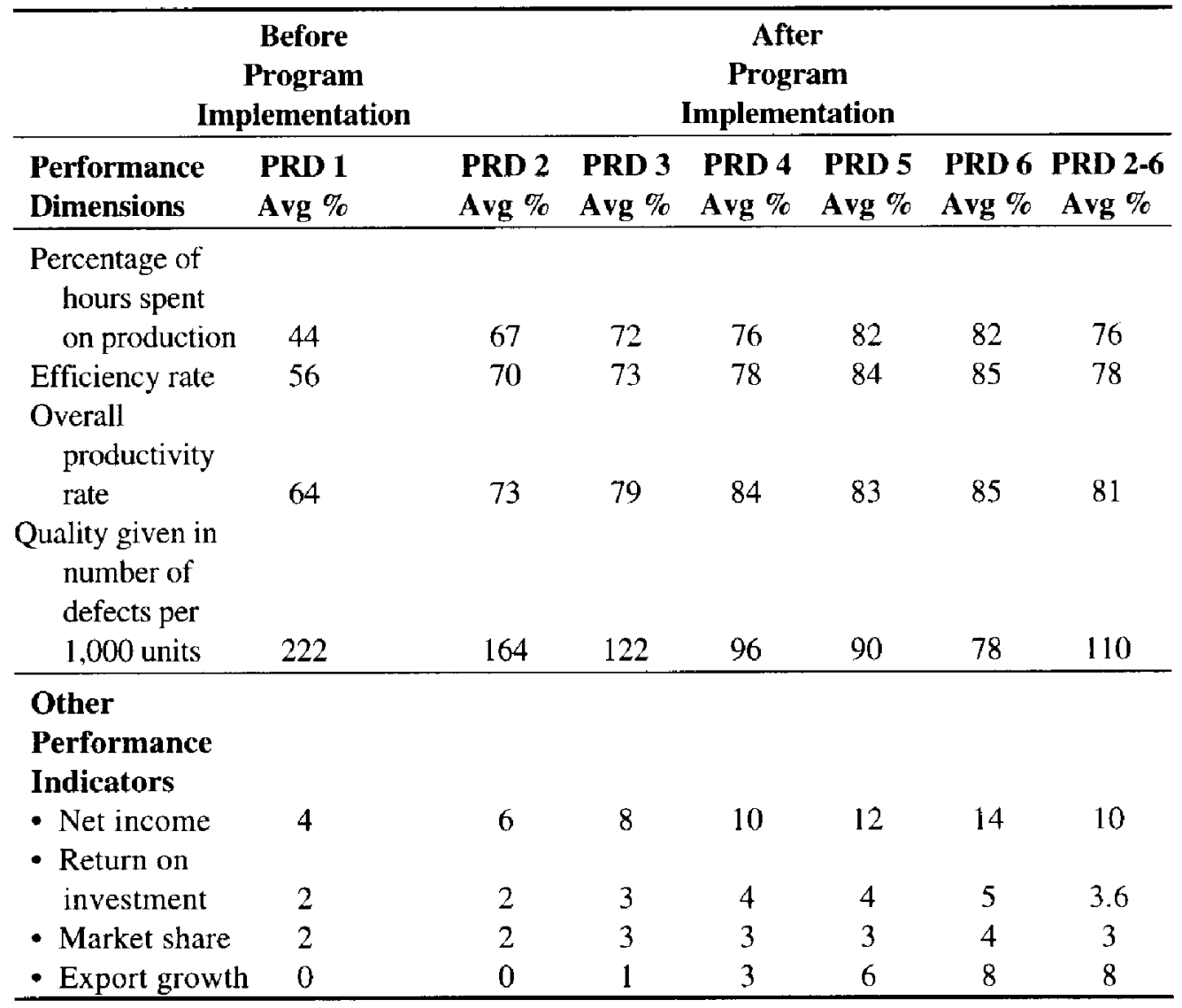

\section{Executive Follow-up Interviews}

During follow-up interviews, the plant manager, the human resource manager, the operations manager, the information systems manager, and the plant controller all expressed overwhelming support for the Internet aided self-managed teams program. They also claimed that the program was making a contribution to organizational performance, quality of products produced, and quality of work life in the plant.

The plant manager indicated that his plant gained 12,000 hours in the production area due to reduced absenteeism and active participation by teams. He claimed that the proportion of employee days missed dropped from $16 \%$ per year to less than $7 \%$ for the whole plant. The human resource manager, the operations manager, and the information system manager considered the program to be a highly successful method of controlling employee turnover, unproductive time, production costs, and advertising costs. The human resource manager stated that his firm was able to save $\$ 600,000$ in turnover related costs in two years due largely to the Internet aided self-managed teams program. 
All managers expressed confidence that improvements in quality and performance in their plant were made possible by the implementation of the Internet aided self-managed teams approach. They also indicated that there had been no other major changes in activities or incentives in their plant for the past several years that could account for these gains. They also remarked that there were no major shifts or changes related to the state of the economy or the competitive environment within their region.

Further analysis of the impact of the program on organizational performance was accomplished through the use of the plant-reported cost saving data. The plant controller estimated that the total costs of the program 30 months after it began was about $\$ 3.9$ million, $\$ 3$ million of which was the cost of maintenance and equipment including the hardware and software. The hardware and software were under maintenance contract that included training for the first year. Other cost items included $\$ 260,000$ in fees for the consulting group, $\$ 300,000$ for the original training, and $\$ 340,000$ to implement several of the recommendations. He also estimated that in the 30 month period, the plant had realized $\$ 2.5$ million in one-time saving, and approximately $\$ 1.9$ million per year in continued cost savings from recommendations by the consulting group and decreased customer complaints. Other advantages as a result of the implementation can be seen in the reported management control over production costs, advertising costs, reduced number of defective products, and improved performance. Furthermore, during the 30 months since the project began, the plant was able to reduce operating expenses by $9 \%$ while the plant's gross-return increased almost $11 \%$, and sales increased by $20 \%$.

\section{Summary and Conclusion}

Several significant findings emerged as a result of this study. First, the attitudinal results of this research support claims that IASM team program can improve the quality of work life. Statistical analysis indicates that involvement in the program was positively related to perceived changes in satisfaction with opportunities for employees to accomplish something worthwhile at work while enhancing skills needed for advancement in the organization. Furthermore, participation in the program was positively related to perceived changes in communication throughout the organization, as well as job meaningfulness, challenge, and personal responsibility for work. Statistical analysis also substantiate the research hypotheses that predicted that participants in an IASM teams program would report higher levels of improvement of performance and quality of work life than would nonparticipants.

Second, the performance measures also indicate a positive impact on employee performance. Participants in the IASM teams program tended to increase the percentage of time spent on an actual production and produced better quality products. The link between these favorable changes and the IASM teams program was supported further in the follow-up interviews with key managers in the plant. All of those interviewed indicated that the program made a contribution to the 
organizational productivity, quality of products produced, quality of work life, and overall performance.

The bottom line for these managers, then, was that the IASM teams program was effective to date. They also indicated that the dollar savings and indirect benefits generated by the program were greater than the costs of running it. The program was generally believed to help enhance morale, decrease employee absenteeism, and contribute to organizational goals of increased performance, reduced costs, and improved quality of work. Indications are that those benefits will continue to accrue for the foreseeable future. These findings coincide with the claims of many academicians that implementation of IASM teams can reduce costs, increase productivity, increase employee motivation and commitment, and sustain high performance (King, 1998; Kirkman and Rosen, 1999, Mays, 1999; Mohrman, Cohen and Mohrman 1999).

Finally, the research findings suggest that this team approach tends to make clerical and managerial jobs more demanding since the pace of the job and the work load increases. From the project discussion, self-managed teams heighten quality, time and cost awareness, and interest among all employees. IASM teams aided self-managed teams provided employees with the training and opportunity to analyze problems, as well as the tools to develop solutions. Some employees learned how to correct and solve problems on their own, how to implement changes, and how to get involved in the decision-making process; all these responsibilities make clerical and managerial jobs more demanding, yet at the same time challenging.

There are obvious limitations to the perceptual and self-reported data collected in this study, as well as with correlation analysis of such data. Interview responses from the key managers could be biased since the program was one that they may have personally requested or supported. Thus, even though the results from this study may not be generalizable beyond the organization studied, they are generally consistent with and support many of the positive conclusions about IASM teams program already present in the literature. At the same time, to be fair, this research evaluated one IASM teams intervention. A major change occurred in the organization soon after the IASM teams program was implemented and the fact that the company was performing poorly at the outset of the study which could have placed pressure on workers to make sure that IASM teams worked, both may have influence survey results. However, the IASM teams program was implemented and monitored by a consulting group with substantial experience in team-based systems. In this sense, the study offers further encouragement for those who are considering such programs in their organizations.

A practical conclusion drawn from this study indicates that the introduction of a IASM teams program into an organization further requires the introduction of multifaceted changes in person-job relationships and organizational operations. These changes include training in a variety of new skills, a greater degree of goal setting and feedback for specific tasks, team approaches to problem solving, and the structuring of communication flow between workers and management. 


\section{References}

Alexander, S. (2001). Virtual teams going global - Communication and culture are issues for distant team members. Info World, (Nov. 13), 22, 55.

Alwang, G. (1998). Instant groupware. PC Magazine, (February 10).

Anthony, W. P., Kacmar, M. K., \& Whitfield, M. J. (1985). Evaluation of team-based management: A case study. Journal of Organizational Change Management, 8.2, 17-28.

Bill, D. T. (2000). Contribution influences on an individual's attitude toward a new technology in the workplace. http://www.centurionsys.com/rtcl47.html, (July 13), $1-7$.

Bradley, G. E. (1977). Computerization and some psychosocial factors in the work environment. Managing Job Stress, HEW, U.S. Government Documentation Center, Washington, 3-9.

Brucker, D. (1995). Spurring on reengineering, Fortune. (June 26), 15.

Brunelli, M. (1999). How Harley-Davidson uses cross-functional teams. Purchasing. $127,7,1-44$.

Cayne, D. (1997). The emerging star: The Internet. Forbes, (September 22), 512.

C.rosby, P. (1979). Quality is free: The art of making quality free, New York: McGrawHill, 25-45.

Daft, R. \& Marcic, D. (1998). Understanding Management, 6th ed., New York: Dryden Publishing Co., 51-52.

Daft, R. (1999). Organization theory and design, 8th ed., St. Paul MN: West Publishing Co., 47.

DeMarie, S. M. \& Townsend, A. (1998). Virtual teams: Technology and the workplace of the future. The Academy of Management Executive, (August), Vol. 12 No. 3, 17.

Dumaine, B. (1997). The trouble with teams. Fortune, (September 5), 86-92.

Fister. S. (1999). A lure for labor. Training, (February 9), 36,2 56-62.

Flanagan, P. (1994). IBM one day, Lexmark the next. Management Review, (January), $38-44$.

Forrester Research (1998). U.S. online business trade will soar to $\$ 1.3$ trillion by 2003. http://www. forrester.com or http://ecommerce.gov 6/30/2000, (December). 
Forrester, R. \& Drexler, A. (1999). A model for team-based organization performance. The Academy of Management Executive. Vol. 13 No. 3, (August), 28-49.

Harvey, B. (1999). Technology, diversity, and work culture - Key trends in the next millennium, HR Magazine, 4,11, 58-59.

Herrenkohl, R., Judson, T., \& Heffner, J. (1999). Defining and measuring employee empowerment. Journal of Applied Behavioral Science, Vol. 35 No. 3, (September), 373-389.

Holpp, L. (1994). Applied empowerment. Training, (February) 39-44.

Holtz, S. (1996). Intranets. Communication World, (June/July), Vol. 13 No. 6, 54.

Kezsbom, D. (2000). Creating teamwork in virtual teams. Cost Engineering, 33.

King, W. R. (1998). IT - enhanced productivity and profitability. Information Systems Management, (Winter), 64-66.

Kirkman, B. \& Rosen, B. (1999). Beyond self-management: Antecedents and consequences of team empowerment. Açademy of Management Journal, 42.1, 58-71.

Kirkman, B. L. \& Rosen, B. (2000). Powering up teams. Organizational Dynamics, (Winter), 48-65.

Kling, R. (1996). Computerization at work. CMC Magazine, (August), 1-25.

Lawler, E. E. (1979). Measuring the psychological quality of working life. in L. Davis and A. Cherns (eds.) The quality of work life, 1, New York: Free Press, 123-133.

Marks, M. I., Mirvis, P. H., Hackett, E. J. \& Grady, Jr., J. F. (1986). Employee participation in a quality circle program: Impact on quality of work life, productivity, and absenteeism. Journal of Applied Psychology, 71,2, 61-69.

Massey, Jr., T. (1986). Computers in small business: A case of under-utilization. Industry Week, (Fall), $51-58$.

Mays, W. (1999). Project management meets the Internet. http://users.ids.net/ $\sim$ brim/ sdwth.html or http://www.cisco.com/warp/public (March 3).

McDonough III, E. F. \& Cedrone, L. (2000). Meeting the challenge of global team management, Research Technology Management, 12.

Mirvis, P. H. \& Lawler, E. E. (1984). Accounting for the quality of work life. Journal of Occupational Behavior. 5, 197-212. 
Mohrman, S. A., Cohen, S. G., \& Mohrman, A. M. (1999). Designing team-based organizations: New forms for knowledge work. San Francisco: Josey-Bass Publishers, 40-58.

Ramsey, R. D. (2000). How much technology is too much? - Strategies for humanizing a high-tech workplace. Supervision, 6,1, (January).

Reid, R., Reid, M., \& Associates (1999). Characteristics of high performing teams. http://www.improve.org/teams.html.

Rossman, R. J. (1986). Avoiding the pitfalls in implementing a system. The Office, (October) 35.

Shore, B. (2001). Information sharing in global supply chain systems. Journal of Global Information Technology Management, Vol. 2 No. 3, 27-50.

Sirkin, H. L. (1993). The employee empowerment scam. Industry Week, (October) 58.

Solomon. C. (2001). Managing virtual teams. Workforce, Vol. 6 No. 2, 60-65.

Stokes, Jr., S. L. (1991). IS without managers. Information Strategy: The Executive's Journal. (Fall) 11-15.

Thompson, A. A. \& Strickland, A. J. (2003). Strategic Management Concepts and Cases. Boston: McGraw-Hill Irwin, 226.

Thompson-Jones, M. (1999). Only half of net purchases are paid for online. The Industry Standard, (March 1), http://www.thestandard.com/metrics.

Townsend, A., DeMarie, S. \& Hendrickson, A. (1996), Are you ready for virtual teams. HRM Magazine, (September) 123-126.

Turban, E., McLean, E., \& Wetherbe, J. (1999). Information technology for management, New York: John Wiley \& Sons, Inc.

Turban, E., Rainer, K., \& Porter, R. (2000). Introduction to information technology, New York: John Wiley \& Sons, Inc.

Weiss, M. M., Massey, P. A., \& Song, M. (2001). Getting it together: Temporal coordination and conflict management in global virtual teams. Academy of Management Journal, Vol. 44 No. 6, 1251-1262.

Weston, R. (1997). Manufacturers turn to net for improved supply chain. Computerworld, (November 3), 12.

Zawacki, A. R. \& Lackow, H. (1998). Team building as a strategy for time-based competition. Information Systems Management, (Summer), 36-39. 
Dean Elmuti, Ph.D. is a professor of management and management discipline coordinator in the School of Business at Eastern Illinois University. Previously, he was employed for several years by multinational corporations in the Middle East and the United States. He has published over 60 articles in diverse journals such as Journal of Applied Business Research, Journal of Business Strategy, Quality Progress, Journal of Small Business Management, Production and Inventory Management Journal, and etc., in the area of quality, strategy, and global competitiveness. 